\title{
Surfaces
}

\section{Disorientations: Chinese Literature in the American University}

\section{Pauline $\mathrm{Yu}$}

Volume 5, 1995

\section{DEUXIÈME CONGRÈS INTERNATIONAL SUR LE DISCOURS HUMANISTE (1995)}

SECOND INTERNATIONAL CONFERENCE ON HUMANISTIC DISCOURSE (1995)

URI : https://id.erudit.org/iderudit/1064994ar

DOI : https://doi.org/10.7202/1064994ar

Aller au sommaire du numéro

\section{Éditeur(s)}

Les Presses de l’Université de Montréal

\section{ISSN}

1188-2492 (imprimé)

1200-5320 (numérique)

Découvrir la revue

Citer cet article

Yu, P. (1995). Disorientations: Chinese Literature in the American University. Surfaces, 5. https://doi.org/10.7202/1064994ar

\section{Résumé de l'article}

Ce texte examine les diverses médiations savantes et institutionnelles dans lesquelles la littérature chinoise a été étudiée à l'Ouest; allant des hypothèses dominantes de la philologie du 19ème siècle aux motivations de défense stratégique qui soutenaient les programmes d'étude régionale de l'après-guerre, jusqu'au bourgeonnement de la littérature comparée de l'Est et de l'Ouest; il aboutit à la façon dont la théorie contemporaine occidentale cache parfois et plus souvent rend universelles ses présuppositions. Sans vouloir défendre un essentialisme ou un exceptionalisme culturel chinois, qui isolerait les traditions littéraires chinoises des outils analytiques de l'Ouest, je pense que les concepts dits " mondiaux " doivent montrer leur efficacité à partir d'oeuvres insérées dans des histoires et des contextes très différents.
Copyright (c) Pauline Yu, 1995

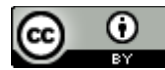

Ce document est protégé par la loi sur le droit d'auteur. L'utilisation des services d’Érudit (y compris la reproduction) est assujettie à sa politique d'utilisation que vous pouvez consulter en ligne.

https://apropos.erudit.org/fr/usagers/politique-dutilisation/ 


\section{Disorientations : Chinese Literature in the American University}

Pauline $\mathrm{Yu}$

pauliney@college.ucla.edu

UCLA

Surfaces Vol.V.203 (v.1.0A - 03/11/1995)

Copyright for texts published in SURFACES remains the property of authors. However, any further publication should be accompanied by an acknowledgement of SURFACES as the place of initial publication.

ISSN: $1188-2492$

\section{ABSTRACT}

This paper examines the various scholarly and institutional mediations by which Chinese literature has been studied in the West, starting with the governing assumptions of nineteenth-century European philology and moving to the defense-strategical motivations behind the development of area studies programs after World War II, to the burgeoning of East-West comparative literature, and finally to the often concealed, but usually overtly universalizing presumptions of contemporary Western theory. While I do not wish to argue for a parochial cultural essentialism or exceptionalism that would insulate Chinese literary traditions from the analytical tools of Western academic practice, I do feel that concepts with claims to be "global" have not really been seriously tested by works embedded in very different histories and contexts, and questions about the function and nature of humanistic discourse have been assumed to be transportable rather than subject to confrontation and transformation from those works. Finally, I point out how the asymmetry in this relationship between Western theory and other traditions has been institutionalized in the typical departmental structure of the American university, a situation that is only now being subject to challenge.

\section{RÉSUMÉ}

Ce texte examine les diverses médiations savantes et institutionnelles dans lesquelles la littérature chinoise a été étudiée à l'Ouest; allant des hypothèses dominantes de la philologie du 19ème siècle aux motivations de défense stratégique qui soutenaient les programmes d'étude régionale de 
l'après-guerre, jusqu'au bourgeonnement de la littérature comparée de l'Est et de l'Ouest; il aboutit à la façon dont la théorie contemporaine occidentale cache parfois et plus souvent rend universelles ses présuppositions. Sans vouloir défendre un essentialisme ou un exceptionalisme culturel chinois, qui isolerait les traditions littéraires chinoises des outils analytiques de l'Ouest, je pense que les concepts dits «mondiaux» doivent montrer leur efficacité à partir d'oeuvres insérées dans des histoires et des contextes très différents.

In our initial exploration of the definitions, functions, and institutional histories of humanistic discourses in the West at the first International Conference on Humanistic Discourses of 1994 (papers from which have already been reproduced through Surfaces) we focused on three principal areas of inquiry: the discursive demarcations of the humanities, both internal (literary vs. non-literary) and external; the extent to which such conceptualizations and distinctions can be translated across cultural boundaries; and the academic context within which such study and translations might take place. As we anticipated the discussions of this second workshop, we wondered whether the same set of questions might be posed with respect to cultural traditions unrelated to those of Western Europe.

A short answer to this speculation, at least in the case of China, is yes. There is, first, an extensive tradition going back to some of the earliest classical Chinese texts that addresses both the nature and the function of the humanities and arts within the larger sphere of human activities. Within this rich and complex discussion both internal distinctions and external relations are delineated, often shifting significantly over time.1 There is, second, an increasingly painful confrontation with the cultural Other, which is initially subsumed (as in relations with European missionaries) but ultimately brought to a crisis in the military sphere. Humiliating defeats put brutally into question a presumed hegemonic universality of the Central Kingdom, its culture, and its values and forced the issue of translation and translatability into a register quite different from that of earlier centuries of contact. 2 And there is, finally, a complicated history of Chinese educational institutions that bears attention, for in their very formation and transformation can be traced the paradoxical legacies of this encounter.

While each of these topics is well worth exploring and, indeed, has been examined by one scholar or another, my interest today is in examining yet another dimension of the overarching set of questions to which we have committed ourselves: the institutional context within which Western-and primarily American-scholars have studied China. Our previous discussions have stressed the importance of teasing out the historical roots of theoretical assumptions and positions, for only a historicized understanding of discursive claims can enable us to eschew easy harmonies and false identifications and preserve the productive tensions between culturally disparate presumptions. Taking a look at what appear's to be a series of mediations by which Western scholars have studied Asia may prove instructive, although the sweep is inevitably going to have to be too broad. 
I shall start with an anecdote which some of you may have heard, for which I apologize. Shortly after moving to California from New York a few years ago I was told by one of my new colleagues, with deep sympathy, that I must miss New York very much. Now, I did have many regrets about having left the urban intensity of the east coast, but being a bit curious as to what the reasons for his remark might be, I responded by asking him why he should think that that might be the case. To which he replied, "Because you're now so much farther away from China."

Needless to say, this was not the answer I expected. I shall refrain from unpacking the various presumptions sedimented within that radically disorienting response; if not reflective of a strangely postmodern sense of global geography, then it surely suggests a firmly Eurocentric one. The most direct route to China from California could only go by way of Paris. Is there a parable lurking in this interchange?

No doubt there is, something to do with what appears to be a series of mediations by which we have studied Asia. The history of Chinese studies in American universities, to take one example, is one whose lines were indeed first drawn in Europe and whose traditions in fact did become most firmly established in France. Philological skills had been honed, of course, since the fourteenth century on the study of classical Latin, Greek, Arabic, Hebrew, and other biblical languages. Serious interest in Chinese culture, however, did not develop until late in the sixteenth century, thanks to Italian Jesuit missionaries like Matteo Ricci and the less well-studied work of countless other scholars. Early lexicographical work on the language itself was largely undertaken by Spanish and Portuguese missionaries, but the discipline of sinology took root in the seventeenth century in French academic institutions. Thus the "University of Paris took care to publicize the work of a number of Jesuit missionary-mathematicians who went to China in 1687 and soon produced a number of pioneering studies on Chinese and Manchu history, and on Chinese religion and ritual." $\underline{4}$

But other scholars throughout Europe in the seventeenth century-among whom Leibniz is probably the best /pp. 7-8/ known-also turned their attention to China, seeking to assimilate Chinese civilization into a grand narrative of Mediterranean culture through such projects as the reconstruction of a supposedly universal language. This established a powerfully diffusionist heritage for much of the work published over the next century. For example, despite respectable scholarly contributions on other topics, the French sinologist Joseph de Guignes published a study in 1759 "in which it is proven that the Chinese are an Egyptian colony," the Chinese script is derived from Egyptian hieroglyphics, and the names of the legendary sage kings of China's prehistoric golden age are actually royal names from the Old Kingdom of Egypt. Even late in the nineteenth century C.J. Ball's The Accadian Affinities of Chinese purported to demonstrate the Mesopotamian origins of the Chinese and their language (Schafer, pp. 29-30). And universalizing theories of history developed over the course of the century contributed on a different plane to versions of this same project.

As one footsoldier in this march of world history and its spirit, early sinology -like all philological efforts-was motivated by two potentially contradictory 
assumptions. On the one hand, it could not but recognize its texts as fundamentally other, different, and undeniably removed from the present in either time or space. This is a critical recognition that, one would assume, would be inherently destabilizing because of the fundamental alienation it presupposes. And yet, on the other hand, and perhaps understandably, it developed procedures, goals, and a rhetorical tone that sought precisely to restabilize what that recognition had set adrift, to recapture an elusive immediacy and anchor the "linguistic remains" that constituted its object of study within fixed and knowable, "universal" semantic limits. This compensatory gesture-let us call it hermeneutical hubris-is encapsulated in yet another anecdote I'll share, about a colleague who recounted his experience in a course on the Rig Veda he took as an undergraduate. The students were reading comfortably along under the professor's guidance. Then around the middle of the term the instructor sent the students out to look at all the scholarly translations of one particular hymn. They came back the next day to say: "But professor, it seems that no two of them have anything in common with any of the others." "Yes, " answered the professor, "and they are all wrong." After which he proceeded to provide his right interpretation. $\underline{5}$

We recognize this scene. More often than not, guardians of textual correctness will marshal equal amounts of erudition and evidence to produce results that cannot help being mutually exclusive. The impulses behind such efforts to accommodate, incorporate, or control that which is distant and different are well known to us, and particularly the political spin that has been put on the story by Edward Said's work on orientalism. Needless to say, neither methodological innocence nor political neutrality are claims that sinology has been inclined to put into question. Individuals steeped in European traditions of scholarship may reject any consideration of Chinese traditions and priorities as indulgences in what one eminent American sinologist disdainfully dismissed as "ethnic criticism" (Schafer, p. 38). The tendency to read China through the filters and lenses of European scholarship and desire evident in the early diffusionist studies has also been reflected in the indulgence of many modern Western sinologists in personal scholarly fetishes redolent of the purest and most undisguised chinoiserie. It is clearly not irrelevant, I think, that the most zealous, die-hard practitioners of nineteenth-century European scholarly approaches to Chinese texts, even late into the twentieth century, have been-to a man-of European stock.

What has been the institutional context in the United States for these developments? Various unrelated acts of generosity in the nineteenth century played key roles in inserting Asian studies into American university curricula. The first endowed chair at the University of California at Berkeley, in fact, was the Agassiz Professorship of Oriental Languages and Literatures, which Edward Tompkins presented to the institution in 1872, 24 years before the founding of the department itself. At Columbia University General Horace Carpentier endowed the Dean Lung Professorship of Chinese in 1901, in memory of his devoted Chinese servant who, we are told, "had embodied such characteristic and self-evident virtues that on his death the General decided that an effort should be made to study the civilization out of which such virtue grew."므 During the next few decades similar positions in Chinese and/or Japanese history, literature, and art 
history were established at other institutions around the country, with motivations and methods only slightly less quaint. Curricula focused on the premodern eras of both countries, with linguistic training-if at allprovided almost exclusively in the classical languages alone. Graduate studies were haphazard at best, consisting of considerable independent reading; of studies abroad-for the fortunate few-with one of the handful of respected European Orientalists claiming expertise in Chinese or Japanese classical texts; and of more lengthy tutelage in China or Japan from distinguished professors in universities there. The research of this small cohort was typically text-oriented, positivistic, and probably appropriately regarded-and self-proclaimed-as an exotic, esoteric sidebar on the American academic scene.

World War II changed all this. With the establishment of the Army Specialized Language Program during the war, crash courses in Asian languages-soon to be recognized as strategic-sprang up nationwide, and along with them an unprecedented emphasis on achieving facility in speaking. After 1945 a new generation of scholars trained in the military service entered the few existing graduate programs in the country in impressive numbers. Possessing advanced language skills and facing a virtually unmined field of opportunities for research, translation, and publication in English, they received their doctorates in relatively short order and provided the basis for the implementation of new programs in Asian literatures at many institutions and the strengthening of existing ones. The Chinese diaspora after 1949 enlarged their ranks with foreign-born scholars whose original interests and training actually focused on the study of Western literatures, and whose critical values usually were drawn from those traditions, but who quickly realized that their future in American universities could be secured rather by exploiting their native linguistic advantages.

Benefiting from a more general expansion in higher education that took place until the early 1970s, Asian studies received significant support from major foundations for research, library collections, graduate fellowships, faculty positions, conferences, and publications. Extensive funding for students and programs was also provided by the U.S. government through the Fulbright program and the National Defense Education Act of 1958, which still supports centers of Asian studies today. With the burgeoning publication of reference works, language textbooks, translations, general histories, and monographic studies, systematic graduate education in Chinese and Japanese became possible, and the number of doctorates awarded doubled approximately every ten years.

Careers were made and important ventures in research and instruction launched, but it can be argued that the area studies programs proliferating over the next generation participated in what Said has termed an "intellectual imperialism" of the mid-twentieth century. We might, of course, choose to take seriously heartfelt defenses of area studies programs as being simply and innocently committed, as a former president of the Association for Asian Studies put it, to "the desire to communicate deep understanding of other societies" and as populated purely by "humble gatherers of facts. "ㅍ But we might also choose to remember what areas 
were contained by area studies programs formed in the fifties and sixties: East Asia, South and Southeast Asia, Africa, Latin America, the Middle East, Soviet Russia and Eastern Europe-each of them politically subjugated or antagonistic to a Western European cultural dominion, whose own study of itself was meanwhile institutionally quite differently constituted, in discrete departments generally defined along national borders. (One local variant of this imperialistic parcelling on the institutional level was embodied in the Master Plan of the University of California, drawn up over 30 years ago, which divided academic responsibility for coverage of these regions between Berkeley, which got Asia-East, South, and Southeast-and UCLA, which got Latin America, the Middle East, and Africa.) Area studies programs focused on those geographical regions that, having for the most part only recently been liberated from colonial rule, or having to recover from the ravages of the second World War, were struggling uncomfortably with the model of the nation-state, and hence politically unstable. Yet even as these struggles were becoming increasingly and ever more painfully evident, Western modernization theory was determined to demonstrate that the entire world could be remade in its image. Learning these exotic languages thus became a strategic activity, and departments of Asian languages and Asian studies expanded and flourished, albeit for largely instrumental purposes, to spread the new universalizing doctrines of political, economic, and social progress.

The social scientists who dominated area studies programs from the midsixties onward turned academic attention in the field toward modern East Asia. They deplored-understandably, but not necessarily for honorable reasons - the antiquarianism of the earlier generation of philologists, for their privileging of classical languages and premodern literature and their refusal to be pragmatic about language learning. Yet whether the goal of scholarship on Asia is defined as "transparent communicability," on the one hand, or "fetishized exoticism," on the other, each alternative makes of Asian literature what has been called a "localized embellishment of the general narrative." 8 How much difference does it make, in the end, whether the story is one of a Mediterranean linguistic and mythological diaspora or the triumphant march of development theory across the globe? We are still likely to be, to recall my opening anecdote, rather far away from China. $\underline{9}$

The discipline of comparative literature, too, has played a crucial role in the sequence of mediated knowledges I have been tracing. Comparative literature was established in this country in 1899 at Columbia University in the English Department, at the height, incidentally, of British imperialist ventures throughout the world.10 Its first real flowering subsequently then took place in the same post-war internationalist context that spawned interest in the strategic importance of Asia, although comparative literature's primary desire was more directly to reaffirm the essential unity of European culture, one which had been sorely disrupted by the second World War. In the mid-fifties, however, a major conference at Indiana proposed the introduction of "East-West comparative literature" into the discourse, and for the next two decades a small group of specialists worked their way through a variety of critical and evaluative positions. They had to wrestle with the old guard comparatist position that only "relationships of fact" provided adequate grounds for comparison; if that were so, then the entire premodern Asian tradition would be off-limits, and with it the 
canonical texts that the old-guard Orientalists took most seriously. Fortunately, the argument was made that "affinities" were just as interesting and certainly "illuminating" as demonstrations of direct influence, so the work of one-on-one comparison between Eastern and Western figures and texts could proceed, albeit often within a kind of methodological and contextual vacuum. Comparisons were inevitably one-sided or unwittingly invidious: if similarities could be shown, it was because something Chinese was just like something Western. Discussions comparing Chinese to Western poets on an individual basis proliferated, elucidating the proleptically "romantic" or "symbolist" practices of the former, and leading quite naturally to more recent claims that China had deconstruction in the fourth century B.C. If differences existed, it was to the detriment of the Chinese example (China "lacked" epic and tragedy, for example, or Chinese fiction suffered from the "limitations" of a strong didactic impulse, or the Chinese poetic tradition did not possess the metaphysical and subjective power that could produce a work as great as "Tintern Abbey"). The critical vocabulary was drawn heavily from the Dictionary of Generalizations, and entire richly varied, heterogeneous traditions became homogenized as unqualified monoliths in the face-off of East and West. In particular, a selected group of East Asian texts and figures became charged with the burden of being "representative," reduced to distillations of an already essentialized culture, which repeatedly was subjected to the measure of so-called literary "universals," values that turned out, to no one's surprise, to be Western ones.

As comparative literature relocated itself within the domain of theory, so, too, albeit slowly, did Asian comparative literature. I remember as a graduate student being cautioned that before moving on to other approaches it would be best to wait until New Criticism had succeeded in displacing positivistic scholarship and impressionistic criticism and had become accepted and established practice in Asian literary studies: such was the power of the desire to be embraced by the evolutionary master critical narrative. Soon, however, "applying" Western theory seemed to provide an intellectually respectable way of dispelling doubts about the comparability of historically unrelated texts or figures. Through such mechanical "applications" we could follow whatever theoretical current prevailed and produce the appropriate reading. And we did, once again subsuming Asian literature to presumed theoretical universals.

By the mid-eighties, however, "we" had multiplied and changed significantly in composition. Western theorists had traveled to China and attracted the attention and interest of cadres of young students studying Western literature, who became remarkably fluent in both the language and the subject matter. Wooed to the States by lucrative graduate fellowships they began to populate East Asian and comparative literature programs here (incidentally keeping many of them afloat, as Americans were choosing instead to go to law school). Then-in a curious enactment and reversal of a colonialist paradigm - having arrived at the metropolitan center they proceeded to transform it, on the margins at least, in the field of Chinese literature, and that of the modern period in particular. By 1990 a major conference at Duke University on contemporary Chinese politics and culture could take place that was completely organized by the first generation of 
these immigrants and that successfully consigned to the wings much of the older generation of scholars trained during the hegemony of social sciences. $\underline{11}$

Although many have acknowledged in relative silence the sea change within the field, the relationship of contemporary theory to the study of East Asian literature constitutes part of the general problematic of comparative literature to which I have already referred. In a review of a book on Nietzsche and Asian philosophy, William Haver chastises the author for failing to call into the question "the founding assumptions of so-called comparative philosophy...: that the comparative philosopher is entitled to the enjoyment of an endowed chair of transcendental subjectivity, that every movement of thinking becomes equally an object for judgment under [his] panoptic gaze..."12 This critique of a comparative philosophy that fails to examine its assumptions and procedures applies with equal salience, I believe, to comparative literature. Let us remember that comparativism itself is very much a nineteenth-century European concept, and the notion of a theoretical model that can comprehend difference an even older Western assumption. Can one comprehend difference without subsuming it? Alice Jardine argues that when comparativism involves the importation and exportation of thought,

it brings with it new problems: descriptivism, summary, anthologism-a certain analogical logic...[O]ne compares A to B according to a model. This model can be an "idea," "principle," "politic," or "structure," over which the comparatist has complete control: he is, like God, "above it all" [somewhat like Haver's occupant of the endowed transcendental chair]. Jacques Derrida has pointed out that this assumption of an ideal that can be applied to two objects is also related to classical ideas of translation, where, again, for any text there is an ideal "text" (the text's meaning) that must simply be transported to another text. A close analysis of the comparative spirit in general reveals that this logic of transportation, this separation of identities and differences, can operate not only abstractly, as intellectual, conceptual imperialism, but concretely as well-most notably in the form of racism and colonialism. $\underline{13}$

Some comparatists have argued that it is more difficult to find similarities than differences between texts of two unrelated cultures, or that the search for similarities is the only way for Asian literature to escape from the "cultural ghetto." 14

I would argue that the risks of unreflective appropriation and hegemonic totalization-what Robert Young characterizes as an "ontological imperialism" that is not accidentally tied to real differentials of power-may be as powerful as those of cultural relativism, for "when Western knowledge or theory comprehends the other, its alterity vanishes as it becomes part of the same."15 Part of the same, but clearly subaltern in this relationship, Asian literatures may find themselves accommodated within a grand narrative, but do they speak? There's another anecdote to recount in this regard: one of the better known American interpreters of European theory 
met the author of a recent comparative work that spans cultural and temporal boundaries, including those of China (which happens to be this author's area of specialization). Over casual dinner conversation our theorist remarked, with absolutely unabashed candor, that he had actually read the author's book and enjoyed it very much, but he "had skipped all the Chinese stuff." One can skip over it, or simply-on respectable theoretical groundsnot include it at all. Another colleague of mine went on record in the student newspaper with the comment that the core curriculum didn't need to be infiltrated or expanded by non-Western or ethnic materials since the Western canon managed to deconstruct itself quite nicely on its own. William Bennett, Allan Bloom, and company might well appreciate this poststructuralist contribution to their old-guard defense of the Great Books.

It seems to me that the enabling assumptions of comparative literature, of contemporary theoretical discourse, and of the relationship of Asian literatures to ideas that have deep roots in specific European and now American intellectual practices, have not been sufficiently interrogated. I am by no means staging a grand essentializing combat between "Asia" and the "West" or arguing for continued claims to a cultural exceptionalism and consequent consignment to an intellectual and institutional ghetto, which, among other things, provides a far too convenient haven to Asianists who'd rather not engage in contemporary theoretical and critical debate. I think it is a problem, however, that, when we do encounter it on the discursive scene, more often than not, we "skip all the Chinese stuff," or simply plunder it for examples to be processed mechanically in support of putative universal constructs. By "we," moreover, I do not mean not just Western scholars.

Perhaps the most important first step is to contextualize the theoretical approaches we deploy; they have been developed, after all, to explain a very concrete set of local, particular cases. Concepts with claims to be "global" have not really been seriously tested by specific examples with very different histories and contexts, even when purportedly dealing with issues concerning the non-Western world. What kinds of questions arise in one place, and are they the same in another? This momentary reflection on the bases of one's critical procedure occurs with disturbing infrequency in contemporary comparative discourse on Asian literature. As long as critics fail to engage in it, the resistance of many East Asianists to the universal claims of these constructs and insistence on the exceptional nature of their subject will, unfortunately, become even more firmly entrenched. I am speaking here not so much of the obdurate sinologists, whose philological methods, as I've argued, participate in usually unacknowledged universalizing projects of their own, but of those who occupy more hybridand perhaps more self-reflective-positions.

I wonder if it's possible to recall an older notion of theory itself as a process of reflection, and self-reflection, rather than the mechanical application of models. Without privileging or romanticizing the other traditions, can we give them a voice in the conversation, while always acknowledging that in our contemporary academic contexts it must inevitably be the case that they are "given" voice? The relationship cannot but be unmediated, but can we at least recognize that fact, rather than proceeding from a position of unreflective neutrality or unquestioned universality? Can the engagement be 
fruitfully reviewed as one of confrontation, rather than accommodation or appropriation? Can the possible resistances of Asian materials be taken back to theory, either to expose the limits of its methods or to transform it altogether? What does looking at China enable theory to say, and what must it put into question? Will we emerge from this confrontation with a less certain sense of the binaries and the boundaries-and not only those of the subject matter. Will we also see our own positions as inevitably hybrid ones? And who will we be? Hopefully not only the scholars of East Asian literature.

If so, then we will have effected a disorientation of a different, and perhaps more salutary nature, than that of my theorist acquaintance who only knew how to get to China by way of Europe. East Asian studies has already literally dis-Oriented itself almost completely in the United States; the penultimate step in the institutional transformation from the world of the exotic carpet bazaar to that of geopolitical finance and faxes was taken when Berkeley's department-one of the last holdouts-recently renamed itself, under tremendous pressure and with considerable resistance, changing from Oriental to East Asian Languages. Differentials of power within the university have also been jostled: just as Asian investors have quietly bought up major buildings and businesses around the country, so extraordinarily well-endowed foundations in each of the three East Asian countries are aggressively contributing to significant development of American academic programs through institutional enhancement grants. The rapidly changing demographics of the American university student population, particularly in California, 16 have also effected a dramatic change in internal power relationships between East Asian and European language departments, to the extent that enrollments bring power. What the late Bill Readings once referred to as "the evacuation of the nation-state as cultural form" 17 has been concretized in the visible evacuation of university students from courses in European literature.

Resources are being reallocated, perhaps, but the "accidents" of institutional history continue to group together in one department three nations (China, Japan, Korea) with no more, and no less, in common with each other-in terms of shared linguistic, intellectual, and political histories - than the European countries, whose languages and literatures are still privileged by virtue of their historical separation into independent academic units. Given the pressures of "enrollment terrorism," will we see departments of European studies taking shape, or being forced into being, at major research institutions? There is extraordinary resistance, I have discovered, to the idea of collapsing the borders of these discrete departments, however costineffective they may be. But if you asked my colleagues in departments of East Asian studies whether they would have preferred to be organized into discrete national units (Chinese, Japanese, Korean), once they'd ceased grousing about the relative privileging of the European literatures, I suspect they'd say no. Not because they have so much in common (more often than not such regional units seem committed to endless replays of the SinoJapanese war or dramas of Korean post-colonial ressentiment) but because they realize, most basically, that in the university there is strength in numbers. 
Moreover, in recent years some of the most exciting scholars of the three East Asian cultures have begun to think seriously about taking advantage of their collocation, but in a very different intellectual and political context from that of area studies programs twenty to thirty years ago. They are beginning to interrogate the interpretive frameworks within which they have been trained, to try to gain a perspective on premodern East Asian societies that is thoroughly cognizant of but not thoroughly conditioned by Western epistemic and teleological schemes, that recognizes the "impurity" or hybridity of any position in the late twentieth century, and that turns a fresh eye on the previously unexamined or unproblematized history of intra-Asian relationships. Such new directions of research will be instrumental in helping us to break out of the binaries of universal and particular, West and East. Finally, in southern California the burgeoning demand for systematic attention to South and Southeast Asia and to Asian American studies is forcing East Asianists to look over both shoulders simultaneously and, among other things, to rethink their intellectual posture and their niche within the university community.

I wonder if similar challenges will be confronted by my Europeanist colleagues. Sooner or later, perhaps, we will all be dis-oriented and disoccidented enough to have worked our way free of the old East-West binary. New dichotomies will no doubt appear, and they will no doubt also be as productive as the old ones in fact were, but perhaps we will be sensitive enough to the truly hybrid, heterogeneous nature of our current positions, and to the ephemerality of our past ones, not to ignore the fact that we stand in them or to think that they will endure forever.

\section{NOTES}

1 While many subsidiary arguments can be teased out from within this extensive textual legacy, some of which would stress, for example, the distinctions between the literary and the non-literary and others of which would oppose the frivolity of the literary to the didactic power of the moral, a more deep-seated and enduring assumption posits the fundamental embeddedness of humanistic pursuits within culture and society and the appropriateness of using accomplishments within them as an index of suitability for political leadership. The best-known example of this assumption is the fact that tests of poetic and prose composition constituted an essential element of the civil service examination for well over a millenium.

2 These lessons of force were imparted from the Opium War of 1840 onward; when even the Japanese prevailed over China in the Sino-Japanese War of 1894-95, the necessity of taking drastic corrective measures became ineluctable. Even so, responses varied between an abject enthusiasm for and embrace of Western learning and values to a dogged defense of traditional Chinese cultural accomplishmets as the only means of salvation.

$\underline{3}$ Some of the most prominent Chinese universities were established by Western missionaries or expressly for the purpose of preparing young 
Chinese youth for study abroad. At Beijing University the department of Chinese literature was not so-called until the abolition of the civil service examination in 1905, and the study of the classics (jingxue) became that of literature (wenxue).

$\underline{4}$ Edward H. Schafer, "What and How Is Sinology?," T'ang Studies 8-9 (1990-91), p. 29.

$\underline{5}$ Recounted by Stephen Owen in his "Philology's Discontents: Response," Comparative Literature Studies 27.1 (1990), p. 75. The point about philology's attempt to restabilize what has been set adrift is also Owen's, ibid. The use of the term "linguistic remains" to refer to philology's objects is Schafer's, p. 25.

$\underline{6}$ Cited by Marius Jansen in «MDUL»Japanese Studies in the United States«MDNM» (Tokyo: The Japan Foundation, 1988), p. 12.

7 Benjamin I. Schwartz, "Presidential Address: Area Studies as a Critical Discipline," Journal of Asian Studies 40.1 (1980), pp. 15, 7.

$\underline{8}$ Rey Chow, "The Politics and Pedagogy of Asian Literatures in American Universities," differences: A Journal of Feminist Cultural Studies 2.3 (1990), p. 36.

$\underline{9}$ This is not to say, of course, that area studies have necessarily remained mired in the cold war mentality of the post-war period and should therefore now be dismissed. On the contrary, the more nuanced contemporary version of what once flourished owing to national defense concerns has succeeded in honing its sensitivity to cultural particularities and offers an important and sophisticated understanding of specific regions of the world that has become ever more crucial in a context of global interdependence, within which the United States is disturbingly parochial and uninformed. See the report prepared by Dr. Jason H. Parker, "Review of the International Programs of the ACLS/SSRC: Current Concerns and Future Priorities," March 21, 1994.

10 A point made by Michael Palencia-Roth at the beginning of his article on "Contrastive Literature," ACLA Bulletin 24.2 (Spring/Summer 1993), p. 47.

11 Papers from this conference have been published in Liu Kang and Tang Xiaobing, eds., Politics, Ideology, and Literary Discourse in Modern China (Durham and London: Duke University Press, 1993).

12 Review of Graham Parkes, ed., Nietzsche and Asian Thought (Chicago: University of Chicago Press, 1991), Journal of Asian Studies 51.3 (August 1992), p. 629.

13 Alice A. Jardine, Gynesis: Configurations of Woman and Modernity (Ithaca and London: Cornell University Press, 1985), p. 14.

14 Zhang Longxi, " Out of the Cultural Ghetto: Theory, Politics, and the Study of Chinese Literature," Modern China 19.1 (January 1993), pp. 71-101. 
15 Robert Young, White Mythologies: Writing History and the West (New York and London: Routledge, 1988), p. 13.

16 In 1980 the ratio of whites to nonwhites at UCLA, for example, was 2:1; twelve years later it was exactly the opposite, with Asians comprising over half of the "minority" constituency.

17 In "For a Heteronomous Cultural Politics: The University, Culture, and the State," Oxford Literary Review, 15.1-2 (1993), p. 167. 